\title{
Role of Visha in Vitiation of Doshas and Guna-A Review
}

\author{
${ }^{1}$ Dr. Shri Ram Saini, ${ }^{2}$ Dr. Durga Lal Sharma \\ ${ }^{1}$ Assistant Prof. Roga Nidana Evam Vikriti Vigyana Department SBLD Ayurved Viswabharti \\ Sardarshar, Churu, Rajasthan. \\ ${ }^{2}$ Prof. \& HOD Agad Tantra Department SBLD Ayurved Viswabharti Sardarshar, Churu, \\ Rajasthan.
}

Received: 10-11-2021 / Revised Accepted: 26-11-2021 / Published: 01-12-2021

\begin{abstract}
Human body is developed by the confluence of Doshas, Dhatu and Mala along with Indriya, Atma and Manas. Doshas are the source for homeostasis when they are normal and produce disease during their disequilibrium state. Dosha in a healthy person performs certain functions based on its Pramana (amount), Guna (quality), and Karmas (function), and any change in any of these leads to illness development. Because of their properties, Visha Dravyas are classified as Tridoshaprakopaka, Laghu, Ruksha, Aashu, Vishad, Vyavayi Teekshna, Vikasi, Sukshma, Ushna, Anirneshaya are the properties or Gunas. Pradhanikhetu is when Visha has an immediate effect without passing through the stages of Sanchay and Prakop. However, it will be deemed a Hetu other than Pradhanik if it deteriorates the healthy Dhatus and causes disease after vitiating the Doshas. It has Gunas that are comparable to Madya's but opposite of Ojas'. As a result, it affects the essence of all Dhatus, Ojas, and causes various types of Vyadhi Visha's effects are influenced by a variety of elements, including the qualities or Gunas of Visha, their power, the nature of the material, and the Prakriti of the person impacted.
\end{abstract}

Keywords: Visha, Poison, Dosha, Guna

\section{INTRODUCTION}

The fundamental factors for the foundation of the body are Dosha, Dhatu, and Mala. In the human body, there are two types of Doshas: Sharirika and Manasika. Sarirakadosha is made up of three Vata, Pitta, and Kaphadoshas that work together to keep the body functioning normally. Rajas and Tamas are the two varieties of Manasika Doshas. Certain ailments are caused by the vitiation of the Sharirika and Manasika Doshas, either separately or in combination. Shifts in the Sharirika Doshas cause shifts in the Manashika Doshas, and vice versa. ${ }^{1}$ Visha is defined as any substance that causes Vishad or discomfort in the body. ${ }^{2}$ Visha causes either vitiation of the healthy Dhatus or death of the healthy person as soon as it enters the body. As a result, Visha is crucial in the manifestation of Vyadhi. One of Visha's synonyms is Gada, which is also a name for Vyadhi. ${ }^{3}$ Visha is a material that

Address for Correspondence: Assistant Prof. Roga Nidana Evam Vikriti Vigyana Department SBLD Ayurved Viswabharti Sardarshar, Churu, Rajasthan; Gmail: drshribams06@gmail.com

How to Cite this Article: Dr. Shri Ram Saini, Dr. Durga Lal Sharma. Role of Visha in Vitiation of Doshas and Guna-A Review. World J Pharm Sci 2021; 9(12): 155-158; https://doi.org/10.54037/WJPS.2021.91205 
causes death or disease when it is put into the body by any channel or comes into touch with a body. It means Visha can either be a Pradhanikhetu, which brings immediate death, or it can fall into one of the other hetu categories, which causes a person's health to deteriorate.Fatality and other effects of a Visha dravya can be attributed to certain properties or Gunas which are said to be ten in Ayurvedic classics. ${ }^{4}$ Visha is believed to be originated at the time of Samudra Manthan. ${ }^{5}$ Based upon its origin it has been classified into two categories i.e. Jangham Visha and Sthavar Visha. ${ }^{6}$ Further, it is also classified as Akritrim Visha and Kritrim Visha where Akritrim Visha is again subdivided into Sthavar and Jangham. Kritim Visha is also called as Garavisa. ${ }^{7}$ Other classifications of Visha include Mahavisha and Upvisha, both of which are significant. Mahavisha refers to Visha Dravyas that have all ten Gunas or properties to their fullest extent, whereas Upvisha refers to Visha dravyas that have these Gunas to a lesser amount. ${ }^{8}$ The dominance of the Gunas possessed by a Visha Dravya determines its activity. e.g. The dominance of the Ruksha Guna will cause the Vatadosha to become vitiated. ${ }^{9}$ People are exposed to numerous forms of Visha nowadays, with different varieties of Visha Gunas dominating in different quantities.As a result, the Doshas in the body become vitiated, and people develop various dermatological, gastrointestinal, and reproductive disorders. In Samprapti of a disease, Visha or poison is said to be Pradhanikhetu or Vyabhcharikhetu based on Guna dominance, Visha Dravya dosage, and time taken to show its effects. The purpose of this review is to investigate the role of Visha in the vitiation of Dosha and Guna.
Aims and Objectives: To evaluate, elaborate and discuss the role of Visha in the vitiation of Dosha and Guna.

Materials: Material related to Visha is collected from Ayurvedic text including Bahatriye, Laghutrye. The available commentaries of Ayurvedic Samhtas have also referred to collect relevant matter. The index, non-index medical journals has also referred to collect information of relevant topic.

Literary review: Poison is defined as any substance that is ingested or generated in the body that causes death or harm. The origin, development, and toxicity symptoms of accumulated toxins (endogenous or exogenous) as well as appropriate treatment methods are all important aspects of health. ${ }^{10}$

Derivation: Visha is derived from the Sanskrit Dhatu "Vish", which refers to Visha's spreading characteristic. Another derivation is "Visha Vipryoge," which depicts Visha's ability to wreak havoc on the body and mind. According Acharya Sushruta the substance that causes sadness (Vishada) is termed as Visha. ${ }^{11}$

\section{Properties of Visha (Poison) ${ }^{12}$}

All poisons have ten qualities, eight Vegas, and twenty-four types of treatments can be used to alleviate their side effects. "Samavayi to Nischestakarnamgunah" is how Guna (properties) is defined. Guna is inactive on its own. When it is linked to Dravyas for the purpose of causing action, it becomes active.

Table no 1. According to Various Acharyas Visha Guna (properties of poison)

\begin{tabular}{|l|l|l|l|l|l|}
\hline Sr. & Charaka & Sushruta & $\begin{array}{l}\text { Astang } \\
\text { Hrudya }\end{array}$ & $\begin{array}{l}\text { Astang } \\
\text { Sangraha }\end{array}$ & $\begin{array}{l}\text { Shargngdhar } \\
\text { Sahita }\end{array}$ \\
\hline 1 & Laghu & Laghu & Laghu & Laghu & ---------- \\
\hline 2 & Ruksha & Ruksha & Ruksha & Ruksha & ---------- \\
\hline 3 & Ushna & Ushna & Ushna & Ushna & Agneya \\
\hline 4 & Tikshna & Tikshna & Tikshna & Tikshna & Chhedi \\
\hline 5 & Sukshma & Sukshma & Sukshma & Sukshma & Sukshma \\
\hline 6 & Vishad & Vishad & Vishad & Vishad & \\
\hline 7 & Vyavayi & Vyavayi & Vyavayi & Vyavayi & Vyavayi \\
\hline 8 & Vikasi & Vikasi & Vikasi & Vikasi & Vikasi \\
\hline 9 & Ashukari & Ashukari & Ashukari & Avari & Yogvahi \\
\hline 10 & Anirdeshya Ras & Avipaki & Avyakta Ras/Avipaki & Avyakta Ras & $\begin{array}{l}\text { Madavaha } \\
\text { Jivitahar }\end{array}$ \\
\hline
\end{tabular}

Charaka, Sushruat, Vagbhata, Yogratnakara and Bhavprakash all are supposed to be ten Guna of Vishas while Sharangdhar supposed to be eight Guna. Out of Ten, nine Gunas of Vishas are similar according to Charaka, and Vagabhata,
Yogratnakara and Bhavprakash. Charaka supposed Anirdeshya Ras instead of Sushruta, Yogratnakara, Bhavaprakash and Astang Sangrah supported to be Avipaki. But Ashtanghrudya supposed both means, Avyakta Ras (Anirdeshya Rasa) and Avipaki 
Table no 2. Properties of Poisons \& Their Mechanism of Action: As per Sushruta, Charaka \&Vagbhata

\begin{tabular}{|c|c|c|c|c|}
\hline Sr. & Guna & Sushruta & Charaka & Vagbhata \\
\hline 1 & Ruksha & VataPrakopak (AggravatesVata) & As Sushruta & As Sushruta \\
\hline 2 & Ushna & $\begin{array}{l}\text { Rakta\& Pita Prakopak } \\
\text { (Aggravates Pita \&Rakta) }\end{array}$ & $\begin{array}{l}\text { Pita Prakopak } \\
\text { (Aggravates } \text { Pita ) }\end{array}$ & As Sushruta \\
\hline 3 & Tikshna & $\begin{array}{l}\text { Buddhi, Moha, } \\
\text { MarmaChheda(Destroys the vital } \\
\text { organs) }\end{array}$ & As Sushruta & $\begin{array}{l}\text { Rakta \& Pita Prakopak } \\
\text { (Aggravates Pita \& Rakta) }\end{array}$ \\
\hline 4 & Sukshma & $\begin{array}{l}\text { ShighraPraveshuStrotase (poison } \\
\text { enters even capillaries) }\end{array}$ & $\begin{array}{l}\text { VataPrakopak } \\
\text { (AggravatesVata) }\end{array}$ & As Sushruta \\
\hline 5 & Ashu & $\begin{array}{l}\text { Shighra Prana Haranam(Spread } \\
\text { fast \& rapidly fetal) }\end{array}$ & Spread fast & Rapidly fetal \\
\hline 6 & Vyavayi & $\begin{array}{l}\text { Vyavayat (Spread all over body } \\
\text { decidedly fetal \& Death) }\end{array}$ & $\begin{array}{l}\text { Spread without } \\
\text { transformation }\end{array}$ & $\begin{array}{l}\text { Spread } \\
\text { transformation }\end{array}$ \\
\hline 7 & Vikashi & $\begin{array}{l}\text { Dosha, Dhatu, Mala Nasha } \\
\text { (Disintegration of Dosh,Datu\& } \\
\text { Mala) }\end{array}$ & As Sushruta & $\begin{array}{l}\text { Disturbances of Marma } \\
\text { point }\end{array}$ \\
\hline 8 & Vishada & Vishadatva (Non Sticky) & Not stop by body & Not stop by body \\
\hline 9 & Laghu & $\begin{array}{l}\text { Du-Chikitsya (makes treatment } \\
\text { difficult) }\end{array}$ & $\begin{array}{l}\text { Diminishes Response } \\
\text { to Treatment }\end{array}$ & $\begin{array}{l}\text { Difficult to remove from } \\
\text { body }\end{array}$ \\
\hline 10 & Avipaki & $\begin{array}{l}\text { Dur-Haram (makes it's } \\
\text { elimination difficult) }\end{array}$ & 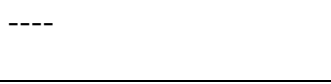 & Dose not get assimilated \\
\hline
\end{tabular}

Mechanism of action of poison ${ }^{13,14}$

The Tikshna (Sharp) property of poison causes Inability of discriminate to intellect \& injury to the vital organ, Sukshma (Minute) Guna permits free entry of poisons to the remote sites of the body causing derangement. Early destruction of living will be occurred due to Ashukari(Quick Acting) property, Spread out in the entire body by its Vyavayi (Diffusive) property and the destruction of body essence due to Vikashi(Disintegrating) Guna. The Poison never adhere due to its Vishad (Vivid) property and difficult to cure due to Laghu (Light) property, while it will be excreted hardly due to its Avipaki (Indigestible) Property.

\section{Discussion}

Poison that enters the body through the mouth or through the parenteral route affects the Rakta Dhatu first, vitiating the Kapha, Pitta, and Vatadoshas, as well as their Ashayas, before reaching the heart (Hridaya). ${ }^{15}$ However; due of the Ashukari and Vyavayi qualities, the spreading process takes a very short time. Blood is a vital vehicle for poison to spread quickly. ${ }^{16}$ According to Sushruta Kalpasthana, poison contains all of its qualities in Tiksna form, vitiating all of the Doshas. Visha spreads throughout the body, vitiates Dosha and Dhatus, causes signs and symptoms, and causes sickness, according to Acharya Vagbhatta. After vitiation, these Doshas lose their natural properties and are unable to absorb the Visha. The patient becomes comatose when vital centres regulating respiration and other bodily functions are surrounded by the disordered Kapha. Life remains hidden in his body, but his sensory and motor functions are apparently absent. ${ }^{17}$

\section{Conclusion}

It may be concluded that Doshas are in charge of regulating physiological functions when they are in their normal state. Because poison's complete qualities are acute in nature, it causes vitiation of all Doshas. Because of the vitiation of Vatadi Dosha, the body is unable to digest the Visha, posing a threat to the living.

\section{REFERENCE}

1. Murthy Srikanta K.R, Clinical Method in Ayurveda, chapter 2, Choukhambha Orientalia Varanasi, ed 3, page 8-9

2. Vaidya YadhavjiTrikamjiCharak Samhita Ayurved Deepika Vyakhya, Varanasi, Chaukhamba SurbhartiPrakashan, Reprint, Charak Chikitsa Sthana Chakrapani Commentary, 2011; 23(5): 570.

3. Vaidya Kushwaha Harishchandra, Charak Samhita Ayushi Vyakhya part-1, Varanasi, ChaukhambhaOriantelia, Reprint, Charak Nidan, 2009; 1(5): 510.

4. Vaidya Kushwaha Harishchandra, Charak Samhita Ayushi Vyakhya part-2, Varanasi, ChaukhambhaOriantelia, Reprint, Charak Chikitsa, 2009; 23(24-27): 580-581.

5. Dr. Pandey Kashinath \& Dr. Chaturvedi Gorakhnath, Charak Samhita Vidyotini Hindi Vyakhya, Part 2, Varanasi, Chaukhambha Bharati Academy, Charak Chikitsa, 2006; 23(4-5): 624.

6. Dr. Sharma Anantram, Susruth Samhita SusruthvimarshinihindiVyakhya, part-2,Varanasi, Chaukhamba SurbharatiPrakashan, Reprint, susruthkalpasthana, 2010; 2(3): 17 
7. Mitra Jyotir, Astang SamgrahaSasilekha Sanskrit Commentary, Varanasi, Chaukhambha Sanskrit Series Office, Astang Sutra, 2008; 40(10): 844.

8. Shastri kashinath, Rasatarangini, Motilal Banarasidas, reprint, chapter, 2014; 24(6): 648.

9. https://www.nhp.gov.in/visha-upavisha-metals-in-ayurveda_mtl

10. https://www.medicinenet.com/poison/definition.htm

11. Murthy. Prof. K.R. Srikantha, Sushruta Samhita Kalpa sthana 3/21, (Vol.II) Chaukhambha Orientalia, Varanasi, 2010; 432.

12. Sharma. Prof. Priyavrat., Charaka Samhita, Chikitsasthana, 23/6, (Vol.II), Chaukhambha Orientalia, Varanasi, 2011; 365.

13. Sharma. Prof. Priyavrat, Charaka Samhita, Chikitsasthana, 23/25-27, (Vol.II), Chaukhambha Orientalia, Varanasi, 2011; 366

14. Murthy. Prof. K.R. Srikantha, Sushruta Samhita Kalpasthana 2/19-21, (Vol.II) ChaukhambhaOrientalia,Varanasi, $2010 ; 422$.

15. Tripathi. Dr. Brahmanand, Astanga Hridaya of SrimadVagabhata, Uttartantra-35/9-10, Chaukhambha Sanskrit Pratishthan, Delhi, 2009; 1144.

16. Sharma. Prof. Priyavrat., Charaka Samhita, Chikitsasthana, 23/42(Vol.II), Chaukhambha Orientalia, Varanasi, 2011; 369.

17. Murthy. Prof. K.R. Srikantha, Sushruta Samhita Kalpasthana3/27-28, (Vol.II) Chaukhambha Orientalia, Varanasi, 2010; 433. 